\title{
Spontaneous idiopathic spinal epidural hematoma: two different presentations of the same disease
}

\author{
Hematoma epidural espinhal espontâneo: duas diferentes \\ apresentações da mesma doença
}

Hematoma epidural espinal espontáneo: dos diferentes presentaciones clínicas de la misma enfermedad

\author{
Asdrúbal Falavigna' \\ Orlando Righesso² \\ Alisson Roberto Teles ${ }^{3}$ \\ Thiago Hoesker ${ }^{4}$
}

\begin{abstract}
We report two cases of spontaneous spinal epidural hematoma with different clinical presentations without precipitating factors and a brief review of the literature. Our case first developed acute and had progressive cervical spinal cord signs that determined emergency decompressive laminectomy. On the other hand, the second patient, who was chronic, was operated almost five months after the initial symptoms and the radiological diagnosis was a large facet cyst. Early surgical intervention is the chosen treatment for spontaneous spinal epidural hematomas. Spinal surgeons should bear in mind that spontaneous spinal epidural hematomas may have different clinical presentations according to their location in order to perform a differential diagnosis.
\end{abstract}

\section{RESUMO}

Os autores relatam dois casos de hematoma epidural espinhal espontâneo com diferentes apresentações clínicas e sua revisão da literatura. $\mathrm{O}$ primeiro paciente apresentava sinais e sintomas de compressão medular cervical, necessitando de laminectomia de urgência, enquanto no segundo paciente, que era crônico, havia sintomatologia de lombociatalgia por compressão nervosa de evolução de cinco meses e com diagnóstico radiológico de cisto facetário. A intervenção cirúrgica precoce é o tratamento de escolha para os hematomas epidurais espinhais espontâneos. Os hematomas epidurais espinhais espontâneos, conforme a localização na coluna vertebral, diferem na apresentação clínica e no manejo. $\mathrm{Na}$ região lombar, o diagnóstico diferencial deve ser feito com patologias degenerativas.

\section{RESUMEN}

Fueron relatados dos casos de hematoma epidural espinal espontáneo con diferentes presentaciones clínicas sin factores precipitantes, y fue hecha una breve revisión de la literatura. Nuestro caso 1 tuvo un desarrollo agudo y mostró señales progresivas en la columna cervical que determinaron una laminectomía descompresiva de emergencia. Por otro lado, el segundo paciente, crónico, fue operado casi cinco meses después de los sintomas iniciales y el diagnóstico radiológico fue de un gran quiste sinovial. La intervención quirúrgica temprana es el tratamiento de elección para hematomas espontáneos epidurales espinales. El tratamiento quirúrgico representa la forma más común de terapia para todos los tipos de presentaciones clínicas. Debemos considerar que el tratamiento conservador (o no) sea más común en casos de presentación leve, principalmente en pacientes con hematoma espinal crónico. Para realizar un diagnóstico diferencial, los cirujanos deben recordar que los hematomas epidurales espinales espontáneos pueden tener distintas presentaciones clínicas según su ubicación.

\footnotetext{
Universidade de Caxias do Sul - UCS - Caxias do Sul (RS), Brazil.

'MD, PhD, Professor of Neurosurgery at Universidade de Caxias do Sul - UCS - Caxias do Sul (RS), Brazil.

${ }^{2} \mathrm{MD}, \mathrm{MSc}$ Orthopedist, Bento Gonçalves (RS), Brazil.

${ }^{3} \mathrm{MD}$, Universidade de Caxias do Sul - UCS - Caxias do Sul (RS), Brazil.

${ }^{4}$ Medical student at Universidade de Caxias do Sul - UCS - Caxias do Sul (RS), Brazil. 
KEYWORDS: Hematoma, epidural, spinal; Laminectomy
DESCRITORES: Hematoma

epidural espinal;

Laminectomia
DESCRIPTORES: Hematoma

espinal epidural;

Laminectomía

\section{INTRODUCTION}

Spontaneous spinal epidural hematoma (SSEH) is a rare disease, with an estimated annual incidence of 0.1 cases per 100,000 individuals ${ }^{1}$. The typical manifestations are sudden onset of severe back or neck pain, followed by symptoms and signs of rapidly evolving nerve root and spinal cord compression ${ }^{2}$. Far less frequently, patients with SSEH may present with slowly progressive, chronic or relapsing symptoms or with neurological signs and symptoms that mimic intervertebral disc prolapse. The therapeutic outcome depends on the delay between diagnosis and surgical decompression ${ }^{3}$. The authors report two cases of SSEH with different clinical presentations without precipitating factors, and a brief review of the literature.

\section{CASE 1}

A 48-year-old man presented with a sudden severe neck pain during the night after getting up to go to the bathroom. After 12 hours, the patient developed weakness in both upper limbs. The neurological examination revealed hypereflexia and weakness in the upper limbs. There was no previous history of trauma, comorbidities or use of medicines. Spinal magnetic resonance imaging (MRI) revealed the presence of a cervical posterior hyperintense lesion on T2-weighted image extending from $\mathrm{C} 4$ to $\mathrm{C} 6$ with anterior displacement of the spinal cord (Figures 1A and B). The patient underwent laminectomy of C4-C6 followed by evacuation of the hematoma 48 hours after the onset of the symptoms. No sign of vascular malformations in the duramater was observed during surgery (Figures 1C, $\mathrm{D}$ and $\mathrm{E}$ ). The patient made an excellent recovery from the preoperative symptoms 12 hours after surgery.

\section{CASE 2}

A 76-year-old man presented with low back pain irradiating to the right lower limb over the past 4 months. He had hypertension and a previous ischemic stroke 14 years earlier. The medical drugs in use were methyldopa, hydrochlorothiazide and enalapril. Neither anticoagulant nor antiplatelet drugs were reported. Neurological examination revealed bilateral quadriceps paresis grade IV and right tibial anterior paresis grade III, hypoesthesia in the right L5 dermatome, normal tendinous reflexes and Lasègue's sign at $20^{\circ}$ in the right lower limb. The MRI revealed a posterior heterogeneous lesion hyperintense on T1-weighted and hypointense on T2-weighted views at the L3-L4 facet with cauda equina compression (Figure 2A and B). The preoperative radiological diagnosis was facet cyst. An L3 laminectomy was
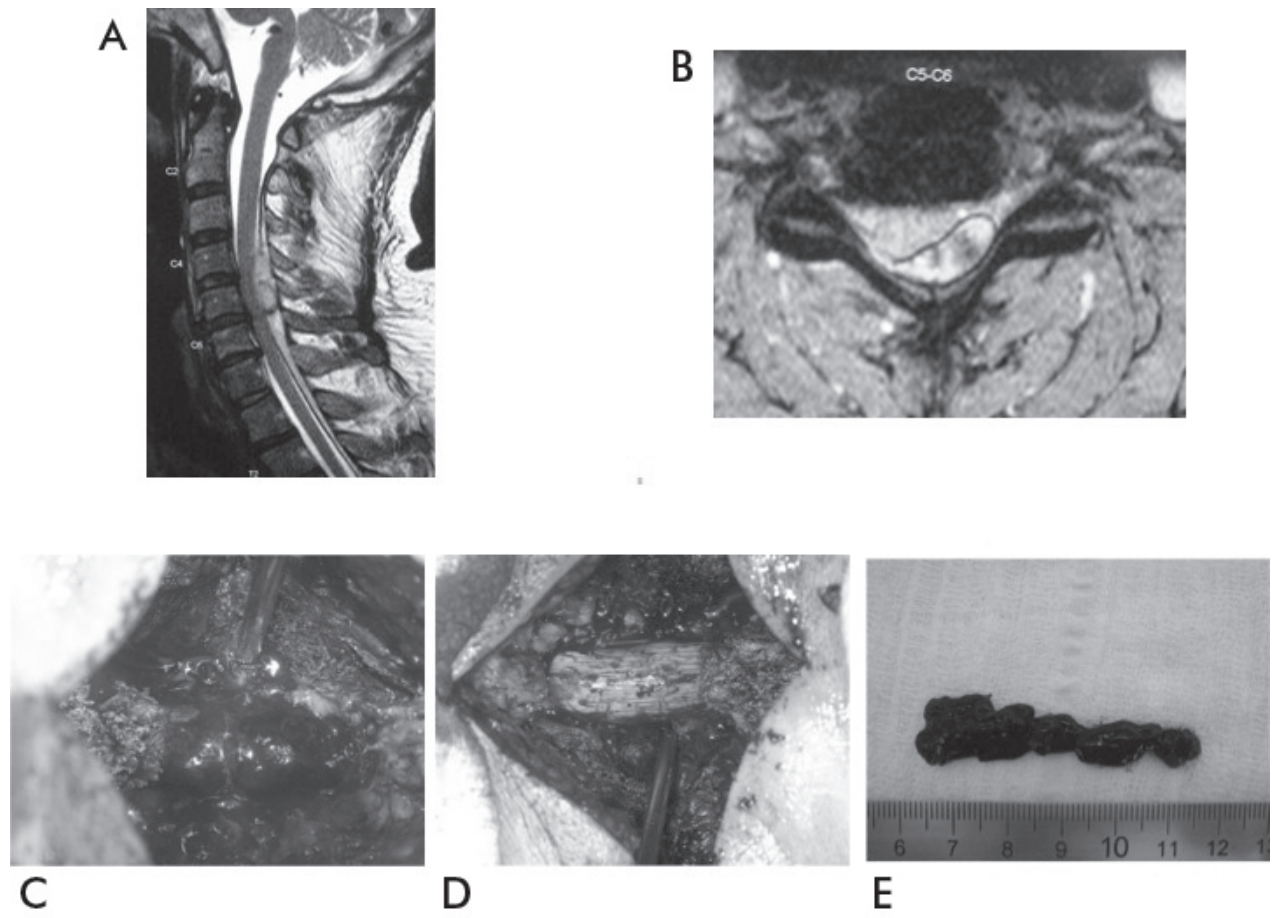

E

Figure 1

Sagittal (A) and axial (B) T2-weighted magnetic resonance imaging scans showing the epidural hematoma extending from C4 to C6 with anterior displacement of the spinal cord. Intraoperative aspect of the epidural hematoma (C). Total hematoma removal $(D, E)$ with no sings of vascular malformation of the duramater. 
performed and a grayish lesion was visualized (Figures 2C and D). The lesion was firmly and well defined (Figure 2E). Total resection was accomplished and the lesion was sent for histopathological examination. This revealed an organized hematoma (Figure 3). The patient recovered from paresis and sensibility after three months.
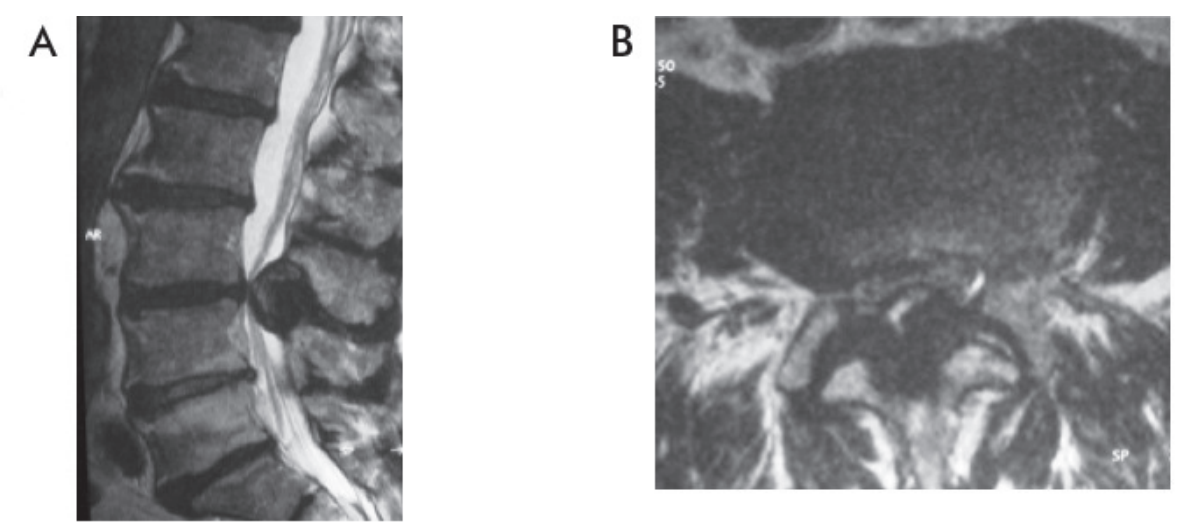

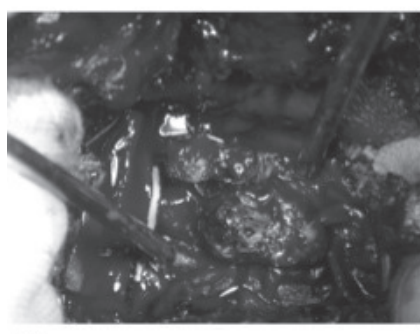

C

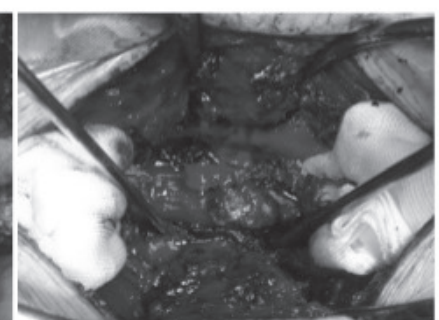

D

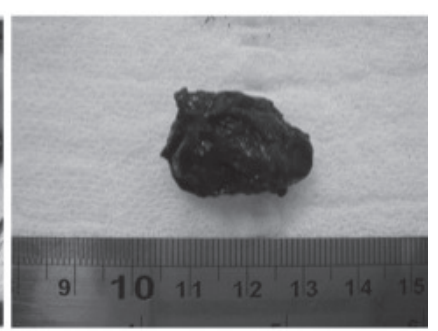

E

Figure 2

Sagittal (A) and axial (B) T2-weighted magnetic resonance imaging scans showing the hematoma with cauda equina compression. Intraoperative aspect of the chronic epidural hematoma (C, D and E).

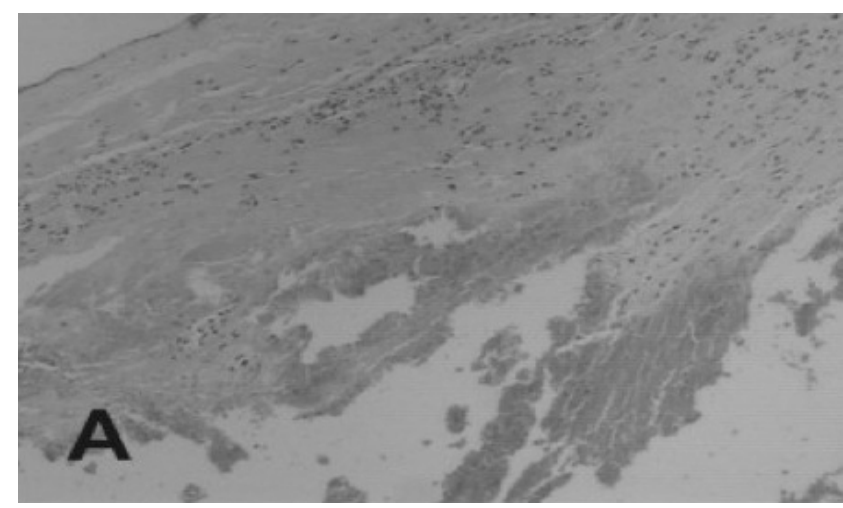

Figure 3

Histopathology of the lesion showing connective tissue surrounding the hematoma (hematoxylin and eosin, 40X).

\section{DISCUSSION}

Spinal epidural hematoma is a rare but significant neurological condition. It is most frequent after the fourth or fifth decade ${ }^{4}$. The male:female ratio is $1.4: 1^{2}$. The most common sites of an SSEH are the cervicothoracic region and thoracolumbar region ${ }^{4,5}$. In patients younger than 40 years old, the majority of SSEHs occurs near the cervicothoracic junction; in patients aged 41 to 80 years, there are

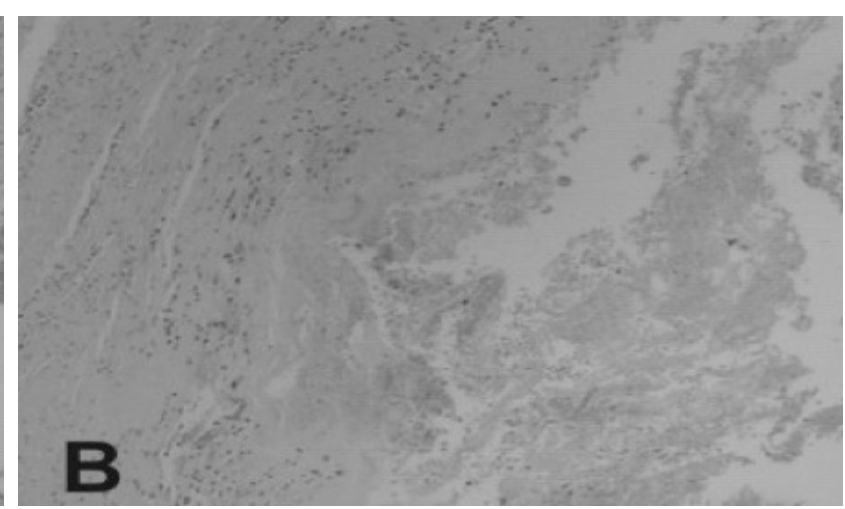

two peaks, including the cervicothoracic junction and the thoracolumbar junction ${ }^{6}$. Krepell ${ }^{7}$ published a meta-analysis of 613 patients with spinal hematoma. In this study, epidural spinal hematomas are by far the most common type of spinal hematoma (461 of 613 cases, corresponding to about $75 \%$ ), followed by subarachnoid hematomas (96 of 613 cases, 15.7\%) and subdural hematomas (25 of 613 cases, $4.1 \%$ ). 
Certain precipitating factors are suggested to correlate with the disease, such as anticoagulant therapy for prosthetic cardiac valves, therapeutic thrombolysis for acute myocardial infarction, hemophilia B, factor XI deficiency, long-term aspirin use as a platelet aggregation inhibitor, and vascular malformation ${ }^{8}$. Idiopathic cases, in which no predisposing factor can be identified, account for approximately $40 \%$ of all cases ${ }^{2}$. Analysis of a large series of cases of SSEH suggested a correlation between SSEH and the coexistence of arterial hypertension ${ }^{9}$. However, a comparison of these findings with data from the Hypertension Detection and Follow-up Program Cooperative Group demonstrated that there was no difference between the percentage of hypertension in the SSEH group and the percentage of hypertensive persons in a population that underwent home screening of their blood pressure. On the basis of this finding, it was concluded that there is no evidence that arterial hypertension plays a role in the etiology of SSEH ${ }^{10,11}$. None of the presented cases had precipitating factors. Although the patient presented in the second case had a previous ischemic stroke, he did not take any antiplatelet or anticoagulant therapy.

The origin of these hematomas has been discussed in the literature ${ }^{10}$. According to most researchers, SSEHs arise from the epidural venous plexus in the spinal epidural space because it lacks venous valves, and undulating epidural hematoma is a sudden stabbing neck or back pain that progresses toward paraparesis or quadriparesis, depending on the level of the lesion and the nerve root ${ }^{7}$. Theoretically, it occurs because the thin-walled venous plexuses are vulnerable to rupture with abrupt changes in venous pressure $^{12}$. This seems to explain why the majority of the cases of SSEH is in the dorsal aspect of the epidural space, where the venous plexus resides ${ }^{9,12,13}$. Shin ${ }^{5}$ propose that idiopathic SSEH is probably induced by a rise in the intrathoracic pressure or the intra-abdominal pressure caused by motion.

The radiological diagnosis is done by means of MRI, a noninvasive and accurate method that demonstrates the localization of the lesion as well as its effects on the spinal cord and spinal nerves. It typically shows biconvex hematomas in the epidural space with well-defined borders tapering superiorly and inferiorly ${ }^{14}$. In the first 24 hours, an epidural hematoma is uniformly isointense with the cord on T1 weighted images. On T2 weighted images it is usually hyperintense, although it may be heterogeneous ${ }^{1,15,16}$. An important feature is the early detection of deoxyhemoglobin. It gives rise to low signal intensity due to a local magnetic susceptibility effect, and this is most obvious on T2 weighted gradient echo sequences. By 48 hours, the hematoma signal is increased on T1 weighted images and remains hyperintense on $\mathrm{T} 2$ weighted sequences ${ }^{1,15,16}$.

The initial manifestation of SSEH is non-specific and easily misdiagnosed ${ }^{3,17-20}$. In the cervical region, the small diameter of the spinal canal results in symptoms of spinal cord compression as complete paraplegia or tetraplegia, urine or stool retention or incontinence 5 . In the lumbar region, the larger diameter of spinal canal allows the expansion of the hematoma, and it can be underdiagnosed. As in the second case, this situation can mimic a nonspecific low back pain. Groen and Van Alphen ${ }^{21}$ published a meta-analysis of 333 cases of SSEH. They observed only $9(2.7 \%)$ chronic cases, defined as an evolution of more than 21 days, and most of these cases are located in the lumbar region (8/9). The differential diagnosis of SSEH includes intervertebral disc herniation, acute ischemia of the spinal cord, epidural tumor or abscess, spondylitis, transverse myelitis, or even a dissecting aortic aneurysm and acute myocardial infarction ${ }^{22-24}$. In the presented cases, we could observe two different clinical manifestations of the SSEH, probably due to their location. In case 1, the hematoma in the cervical region presented acutely with severe local pain and signs of spinal cord involvement due to the limited extradural and subdural spaces of the region and the lower spinal cord capacity to support compression. In the second case, the patient presented with chronic and progressive symptoms of low back pain and signs of nerve involvement due to the greater spinal nerve resistance to compression and greater spinal complacency at the lower lumbar regions.

Early surgical intervention is the treatment of choice for spontaneous spinal epidural hematomas, especially at the cervical and thoracic locations that usually are presented with fast progression of neurological deficit ${ }^{3,25,26}$. In chronic cases, the surgical treatment should be indicated for the management of low back pain ${ }^{5}$. The procedure includes decompressive laminectomy and hematoma removal. The less severe the preoperative symptoms are and the more quickly surgical decompression can be performed, the better are the chances for complete recovery ${ }^{5}$. Conservative treatment has also been reported, and it is employed only when neurological deficits improve in the early phase or in the coexistence of coagulopathy ${ }^{11}$. The literature presents some cases with spontaneous resolution, especially in the lumbar region ${ }^{24,27}$. Our first case had progressive cervical spinal cord, while the second patient had a chronic low back pain lasting four months before diagnosis. Despite the different symptoms, both made a complete recovery from the symptoms.

It is important to keep in mind the differential diagnosis of spontaneous spinal epidural hematoma in patients with acute neck pain with or without progressive pyramidal symptoms and in patients with acute lumbar pain when the radiological exams suggest facet cysts. In these cases, the MRI should be performed and surgical interventions, when necessary, lead to significant neurologic improvement.

\section{ACKNOWLEDGMENTS}

We gratefully acknowledge Karina Salgado M.D., PhD, for the histopathological investigation of the second case and doctors Daniel Volquind and Márcio Della Coleta. 


\section{REFERÊNCIAS}

1. Holtas S, Heiling M, Lonntoft M. Spontaneous spinal epidural hematoma: findings at MR imaging and clinical correlation. Radiology. 1996;199(2):409-13.

2. Liu Z, Jiao Q, Xu J, Wang X, Li S, You C. Spontaneous spinal epidural hematoma: analysis of 23 cases. Surg Neurol. 2008;69(3):253-60; discussion 60.

3. Liao CC, Lee ST, Hsu WC, Chen LR, Lui TN, Lee SC. Experience in the surgical management of spontaneous spinal epidural hematoma. J Neurosurg. 2004;100(1 Suppl Spine):38-45.

4. Guzel A, Simsek O, Karasalihoglu S, Kucukugurluoglu Y, Acunas B, Tosun A, et al. Spontaneous spinal epidural hematoma after seizure: a case report. Clin Pediatr (Phila). 2007;46(3):263-5.

5. Shin JJ, Kuh SU, Cho YE. Surgical management of spontaneous spinal epidural hematoma. Eur Spine J. 2006;15(6):998-1004.

6. Groen RJ. Five patients with a spontaneous spinal epidural hematoma (SSEH). Spine. 1999;24(14):1499500.

7. Kreppel D, Antoniadis G, Seeling W. Spinal hematoma: a literature survey with meta-analysis of 613 patients. Neurosurg Rev. 2003;26(1):1-49.

8. Bisson EF, Dumont T, Tranmer B. Spontaneous spinal epidural hematoma in a child with hemophilia B. Can J Neurol Sci. 2007;34(4):48890.

9. Groen RJ, Ponssen H. The spontaneous spinal epidural hematoma. A study of the etiology. J Neurol Sci. 1990;98(2-3):121-38.

10.Groen R. The spontaneous spinal epidural hematoma: a clinical and anatomical study with correlations to the morphology of the internal vertebral venous plexus. Amsterdam: Thesis Publishers; 1997. p. 1-114.
11. Tailor J, Dunn IF, Smith E. Conservative treatment of spontaneous spinal epidural hematoma associated with oral anticoagulant therapy in a child. Childs Nerv Syst. 2006;22(12):1643-5.

12.Patel H, Boaz JC, Phillips JP, Garg BP. Spontaneous spinal epidural hematoma in children. Pediatr Neurol. 1998;19(4):302-7.

13.Hentschel SJ, Woolfenden AR, Fairholm DJ. Resolution of spontaneous spinal epidural hematoma without surgery: report of two cases. Spine. 2001;26(22):E525-7.

14.Fujiwara H, Oki K, Momoshima S, Kuribayashi S. PROPELLER diffusion-weighted magnetic resonance imaging of acute spinal epidural hematoma. Acta Radiol. 2005;46(5):539-42.

15.Avrahami E, Tadmor R, Ram Z, Feibel M, Itzhak Y. MR demonstration of spontaneous acute epidural hematoma of the thoracic spine. Neuroradiology. 1989;31(1):89-92.

16.Lovblad KO, Baumgartner RW, Zambaz BD, Remonda L, Ozdoba C, Schroth G. Nontraumatic spinal epidural hematomas. MR features. Acta Radiol. 1997;38(1):8-13.

17.Alexiadou-Rudolf C, Ernestus RI, Nanassis K, Lanfermann H, Klug N. Acute nontraumatic spinal epidural hematomas. An important differential diagnosis in spinal emergencies. Spine. 1998;23(16):1810-3.

18.Hsieh CF, Lin HJ, Chen KT, Foo NP, Te AL. Acute spontaneous cervical spinal epidural hematoma with hemiparesis as the initial presentation. Eur J Emerg Med. 2006;13(1):36-8.

19. Muthukumar N. Chronic spontaneous spinal epidural hematoma -- a rare cause of cervical myelopathy. Eur Spine J. 2003;12(1):100-3.

20.Sakamoto N, Yanaka K, Matsumaru Y, Nose T. Cervical epidural hematoma causing hemiparesis. Arch Neurol. 2003;60(5):783.
21.Groen R. Non-operative treatment of spontaneous spinal epidural hematomas: a review of the literature and a comparison with operative cases. Acta Neurochir (Wien). 2004;146(2):103-10.

22.Beatty RM, Winston KR. Spontaneous cervical epidural hematoma. A consideration of etiology. J Neurosurg. 1984;61(1):143-8.

23.Phookan G, Lehman RA, Kuhlengel KR. Cervical spinal epidural haematoma: the double jeopardy. Ann Med. 1996;28(5):407-11.

24.Ravid S, Schneider S, Maytal J. Spontaneous spinal epidural hematoma: an uncommon presentation of a rare disease. Childs Nerv Syst. 2002;18(6-7):345-7.

25.Borm W, Mohr K, Hassepass U, Richter HP, Kast E. Spinal hematoma unrelated to previous surgery: analysis of 15 consecutive cases treated in a single institution within a 10-year period. Spine. 2004;29(24):E555-61.

26. Matsumura A, Namikawa T, Hashimoto R, Okamoto T, Yanagida I, Hoshi M, et al. Clinical management for spontaneous spinal epidural hematoma: diagnosis and treatment. Spine J. 2008;8(3):534-7.

27.Yu HP, Fan SW, Yang HL, Tang TS, Zhou F, Zhao X. Early diagnosis and treatment of acute or subacute spinal epidural hematoma. Chin Med J (Engl). 2007;120(15):1303-8.

\begin{tabular}{l} 
Correspondence: \\
Asdrúbal Falavigna \\
Rua Carlos Bianchini, 1744 \\
CEP: 95013-000 - Caxias do Sul (RS), \\
Brazil \\
Phone/Fax: (54) 3222-0684 \\
E-mail: asdrubalmd@gmail.com \\
\hline
\end{tabular}

